\section{O wystawianiu historii. Świadek Zagłady na scenie zbrodni}

Aleksandra Szczepan

TEKSTY DRUGIE 2018, NR 3, S. 309-323

DOI: $10.18318 / \mathrm{td} .2018 .3 .21$
NARODOWY PROGRAM ROZWOJU HUMANISTYKI

Artykuł powstał w ramach projektu badawczego Nieupamiętnione miejsca ludobójstwa iich wpływna pamięć zbiorowq, tożsamość kulturowq postawy etyczne i relacje międzykulturowe we współczesnej Polsce finansowanego ze środków Narodowego Programu Rozwoju Humanistyki (nr 121/NPRH 4 / $\mathrm{H}_{22} \mathrm{a} / 83 / 2016$ ). "gadających głów": zapis rozmów z krewnymi ocalałych, świadkami i sprawcami tylko czasem jest przerywany widokiem filmowanych z bliska okien kamienic, bruku, drzew. W nakręcony przez siebie materiał reżyserka wplotła również archiwalia: przedwojenne zdjęcia żydowskich mieszkańców Jedwabnego, a także - nieodróżnialny na pierwszy rzut oka - materiał z domowego archiwum Szmula Wasersztejna - zmarłego rok wcześniej autora świadectwa o zbrodni w Jedwabnem, które przytoczył w swojej książce Jan Tomasz Gross². Wjednym z włączonych do filmu fragmentów widzimy Wasersztejna wskazującego palcem punkt na zarośniętym trawą polu; kolejne ujęcie pokazuje świadka w otoczeniu

1 Sq̨siedzi, reż. A. Arnold, Agencja Filmowa Telewizji Polskiej, Polska, 2001.

2 J.T. Gross Sąsiedzi. Historia zagłady żydowskiego miasteczka, Pogranicze, Sejny 2000.

\footnotetext{
Aleksandra Szczepan

- literaturoznawczyni i historyczka filozofii, współzałożycielka i członkini Ośrodka Badań nad Kulturami Pamięci na Wydziale Polonistyki Uniwersytetu Jagiellońskiego.

Zajmuje się redefinicjami realizmu w literaturze i sztuce XX wieku, zagadnieniami performatywności pamięci i reprezentacji przeszłości, studiami nad traumą i tożsamością. Autorka książki Realista Robbe-Grillet (Kraków 2015) i artykułów naukowych.
} 
rodziny, kiedy stara się on zarysować rękami na jednolitej murawie kontury kryjówki, w której przetrwał wojnę dzięki pomocy Antoniny Wyrzykowskiej. „Czuję, że to było gdzieś tutaj” - mówi Wasersztejn i kładzie się na ziemi. Resztę relacji zdaje na leżąco: świadek opowiada o budowie skrytki i miesiącach spędzonych pod chlewem, wykonując rękoma ilustracyjne gesty: „Tak leżeliśmy, przykryci gnojem”. Duszna kryjówka z przeszłości przekłuwa na chwilę otwartą płaszczyznę zielonego pola, a pokryta równą murawą łąka staje się równocześnie - w trybie niedokonanej przeszłości - przestrzenią zagrożenia donosem sąsiadów i śmiercią oraz - w sensie dokonanym - sceną ocalenia. „Reenactment - pisał Bill Nichols w kontekście filmów dokumentalnych - wytwarza iterowalność dla tego, co przynależy do jednostkowości historycznego wypadku"3. Indeks krajobrazu i przylegającego do ziemi ciała świadka łączą w chwilowym spięciu, ale i zapętlonym powtórzeniu porządki wtedy i teraz, traumy i codzienności, Zagłady i przeżycia. Niezwykły performans Wasersztejna symuluje i równocześnie wywołuje zarówno cud jego ocalenia, jak i niezwykłą fuzję pamięci zapisanej w ciele świadka i topograficznego miejsca jego traumy.

W niniejszym tekście chciałabym zająć się jednak nie tyle sceną ocalenia, ile sceną zbrodni - zatrudnić językową kalkę z pogranicza kryminalistyki i kryminału, by uchwycić fenomen miejsc powszechnych w pozagładowym polskim krajobrazie: nieoznaczonych, nieupamiętnionych i zarosłych, przemalowanych, wyburzonych i zamieszkanych na nowo, zaśmieconych lub zabudowanych. Nie-miejsc pamięci i miejsc niepamięci" : punktów wysiedleń, zbiórek i egzekucji, ale też ograniczania swobód, stygmatyzacji, upokorzeń i wykluczenia żydowskiej części polskiego społeczeństwa. Interesować mnie będą nie obozy śmierci czy wielkomiejskie getta, ale punkty rozproszonej Zagłady, zlokalizowane w obrębie lub na peryferiach polskich miasteczek i wsi. Nie podejmę się jednak historycznej rekonstrukcji wydarzeń w konkretnej lokalizacji lub socjologicznego studium postaw zamieszkujących jej okolice

3 B. Nichols Documentary Reenactment and the Fantasmatic Subject, "Critical Inquiry" 2008 Vol. 35 , No. 1, s. 8 o.

4 Wyczerpujące opracowanie pojęcia nie-miejsca pamięci w kontekście nieupamiętnionych miejsc ludobójstwa proponuje Roma Sendyka: tejże Pryzma - zrozumieć nie-miejsce pamięci (non-lieux de mémoire), "Teksty Drugie” 2013 nr 1/2, tejże Miejsca, które straszą (afekty i nie-miejsca pamięci), "Teksty Drugie" 2014 nr 1/2. Por. też na temat niepamięci: tejże Niepamięć albo o sytuowaniu wiedzy o formach pamiętania, "Teksty Drugie” 2016 nr 6, a także klasyczny tekst Lecha Mroza: tegoż Niepamięćnie jest zapominaniem. Cyganie-Romowie a Holokaust, „Przegląd Socjologiczny" $2000 \mathrm{nr} 2$. 
społeczności czy wreszcie fenomenologicznej analizy statusu takich miejsc, ale zaproponuję interpretację szczególnych dokumentów wizualnych, które takie lokalizacje równocześnie reprezentują i ustanawiają jako scenę zbrodni. Będą to nagrywane in situ świadectwa wideo naocznych, lecz postronnych świadków wydarzeń, gospodarzy posttraumatycznego krajobrazu: Polaków wciąż zamieszkujących te tereny. Moje przykłady pochodzą z dwóch archiwów gromadzących takie nagrania: Muzeum Pamięci Holokaustu w Waszyngtonie (USHMM) i fundacji Yahad - In Unum (YIU).

Oparte na niezdarnym zapożyczeniu pojęcie, scenę zbrodni, chciałabym rozumieć w podwójnym, forensyczno-teatralnym sensie. Scena będzie więc miejscem zbrodni - przestrzenną lokalizacją, gdzie wydarzył się mord, również masowy, lub inny zbrodniczy czyn, a która nosi, lub przynajmniej powinna nosić, jego ślady - te zaś należy zidentyfikować i zinterpretować.„Miejsce zbrodni [crime scene] - pisze Greg Siegel - jest ustanawiane (i nieustająco przywracane na nowo) poprzez skomplikowane praktyki zaznaczania, obserwacji, obliczeń, interpretacji i przedstawienia. Jest aktywnie tworzone, nie dane wprost, to twór równocześnie materialny i symboliczny"5. Wraz z fotografią i metodami śledczymi miejsce zbrodni było XIX-wiecznym wynalazkiem nowoczesności: właśnie wtedy lokalizacja popełnionego przestępstwa przestaje być scenerią wydarzeń, a zaczyna być tworem z dziedziny nauki i prawa, poddanym procesom „demarkacji, inspekcji i reprezentacji - inscenizacji i odegrania”. „Nie na darmo porównywano zdjęcia Atgeta ze zdjęciami z miejsca przestępstwa"7 - pisał Walter Benjamin o bezludnych przedstawieniach Paryża autorstwa francuskiego fotografa, który trudnił się „odkrywaniem kulis rzeczywistości”, obojętnie przechodząc obok „wielkich widowisk i tak zwanych symboli"8 i skupiając się na opustoszałych podwórkach, schodach i tarasach. To właśnie ten element wytraconego przed chwilą ciepła, aura opustoszałej scenerii, w której unosi się jeszcze widmowa obecność aktorów wydarzeń, charakteryzują scenę zbrodni. Jest to przestrzeń oczyszczona z ingerencji innych osób, otwarta na interpretację detektywa, ale i z gruntu niestała, krucha, wymagająca ostrożności, wyznaczana przez

5 G. Siegel The Similitude of the Wound, "Cabinet” 2011 No. 43, s. 97.

6 Tamże.

7 W. Benjamin Mała historia fotografii, w: tegoż Aniołhistorii. Eseje, szkice, fragmenty, przeł. H. Orłowski, Wydawnictwo Poznańskie, Poznań 1996, s. 124.

8 Tamże, s. 116, 117. 
sieć drobnych znaków, które w każdej chwili mogą ulec zatarciu - dlatego trzeba utrwalić je jak najszybciej na fotografii lub szkicu. Scena zbrodni to relacyjna jakość miejsca, które ukazuje się oczom śledczej podczas wizyty, wizji lokalnej: musi ona odróżnić elementy sceny pierwotnej od wszelkich zanieczyszczeń naniesionych przez czas i ingerencję czynników, które przekroczyły granicę tej forensycznej autarkii.

„Najważniejszą rzeczą jest wiedzieć, co należy obserwować” - twierdzi bohater Zabójstwa przy Rue Morgue Edgara Allana Poe z 1841 roku. „Poszlaki większej wagi leżą zawsze na wierzchu" - dodaje jego towarzysz, detektyw amator Dupin podczas prowadzonego na własną rękę śledztwa. Miejsce/ scena zbrodni to również teren roboczy dla archeologii, zwłaszcza od kiedy jej metody zaczęto wykorzystywać przy badaniu miejsc zbrodni masowych, w tym Zagłady. Caroline Sturdy Colls, jedna z prekursorek użycia nieinwazyjnych metod archeologicznych ${ }^{\mathbf{1 0}}$ do identyfikacji i badań terenów byłych obozów śmierci, pisze: „Miejsca, w których wydarzył się Holokaust, powinny być traktowane jako miejsca zbrodni [crime scenes]. Stanowią bowiem lokalizacje, gdzie wydarzyły się zbrodnie, i tym samym ich krajobraz zawiera dowody [evidence] tych działań"11. Jeśli zaś, jak chcą niektórzy, miejsca te uznać za „materialnych świadków”, to właśnie dzięki śledczej, która potrafi „zlokalizować, zarejestrować, odtworzyć i zanalizować dowody”, takie miejsce-świadek może naprawdę „przemówić”12 . Badanie poszlak leżących „na wierzchu” pozwala miejsca Zagłady traktować jako ewoluujące z biegiem czasu krajobrazy, które stały się polem dla różnych energii pamięciowych oraz często sprzecznych wspomnień dotyczących tego, ,jak i gdzie doszło do wypadków"13. Forensyczna archeologia operuje raczej w logice interpretacji

9 E.A. Poe Zabójstwo przy Rue Morgue, w: tegoż Opowiadania, t. 1, przeł. S. Wyrzykowski, Czytelnik, Warszawa 1986, s. 211.

Takich jak: badania archiwalne, zdjęcia lotnicze, zbieranie świadectw, system informacji geograficznej, lidar, metody fizjograficzne, badanie pierwszej warstwy gruntu, za: C. Sturdy-Colls The Investigation of Historic Missing Persons Cases: Genocide and "Conflict Time" Human Rights Abuses, s. 21, http://eprints.staffs.ac.uk/2795/1/34\%20\%20Sturdy\%20Colls\%20-\%2ohistoric\%2ogenocide\%2ofinal.pdf (18.02.2018), w wersji drukowanej w: Handbook of Missing Persons, eds. S. Morewitz, C. Sturdy Colls, Springer, New York 2016. 2015, s. 265. 
niż pozytywistycznej naukowości, bowiem „nawet miejsce zbrodni [crime scene] jest historyczną kreacją"14.

Ale kategoria sceny zbrodni nosi w sobie również ładunek teatralnej metafory, a te, jak zauważa Grzegorz Niziołek, „znalazły się w centrum niemal wszelkich podstawowych dyskursów poświęconych wydarzeniom Zagłady i pamięci o nich"15. Według badacza można je podzielić na cztery kategorie: odnoszące się do kwestii dystrybucji ról, tożsamości, widzialności/ niewidzialności czy obsceniczności, wreszcie odgrywania i powtórzenia ${ }^{16}$. Usytuowane ${ }^{17}$ świadectwa wideo postronnych, w których mówiący za pomocą swej relacji i gestu na nowo ustanawiają krajobraz Zagłady jako scenę zbrodni, wydają się uruchamiać wszystkie te rejestry: podziału ról między ofiary, sprawców oraz pasywno-aktywnych obserwatorów; ukrywania żydowskiej tożsamości w czasie wojny; aktów (nie)widzenia Zagłady przez postronnych w jej trakcie oraz ustanawiania ram jej widzialności w czasie teraźniejszym; wreszcie odgrywania i powtórzenia, rekonstrukcji przeszłych wypadków in situ w niemożliwym projekcie oddania ,iterowalności jednostkowego wydarzenia".

Dlatego scenę zbrodni chciałabym rozumieć bardziej metaforycznie, jako łączącą te wszystkie porządki „demarkacji, inspekcji i reprezentacji - inscenizacji i odegrania",jako wieloaspektowe pole, na które składają się zarówno atrybuty przestrzenne i topograficzne miejsca, zwykle zatarte ślady zbrodni oraz ludzkie szczątki, jak i performatywna obecność ciała świadka, przez które przeszłość jest wywoływana, ale również opowiadana i wystawiana. Odtwarzaną i wytwarzaną w świadectwach wideo postronnych scenę zbrodni spróbuję opisać za pomocą sześciu kategorii.

Po pierwsze, archiwum. Opisane na wstępie niespełna dwuminutowe nagranie to unikat w wizualnym archiwum Zagłady, w którym postać ocalałego rzadko zostaje zestawiona z otwartą przestrzenią pozagładowego krajobrazu czy sfilmowana w całości cielesnej ekspresji. Spośród ponad 77 tysięcy

14 B. Prager The Act of Digging: Archaeology, Photography and Forensics in "Birthplace" and "Holocaust by Bullets", w: Holocaust Cinema in the Twenty-First Century: Memory, Images, and the Ethics of Representation, ed. by O. Kobrynskyy, G. Bayer, Wallflower Press, New York 2015, s. 61.

G. Niziołek Polski teatr Zagłady, Wydawnictwo Krytyki Politycznej, Warszawa 2013, s. 93.

Tamże, s. 94-95.

Por. J. Walker Moving Testimonies: "Unhomed Geography" and the Holocaust Documentary of Return, w: After Testimony: The Ethics and Aesthetics of Holocaust Narrative for the Future, ed. by J. Lothe, S.R. Suleiman, J. Phelan, Ohio State University Press, Columbus, OH 2012, s. 270. 
świadectw wideo zgromadzonych od końca lat 70. przez największe poświęcone temu zadaniu instytucje ${ }^{18}$, zdecydowana większość została nagrana nie tylko z dala od miejsc, gdzie wydarzyła się Zagłada, ale także w wytłumionej poetyce i w zacisznej scenerii bibliotek lub prywatnych mieszkań, na tle nieruchomego wnętrza: regałów z książkami, obrazów i roślin w doniczkach ${ }^{19}$. Setki podobnych nagrań, możliwych do przeglądania, w zależności od bazy, za pomocą różnych kategorii wyszukiwawczych, tworzy przekraczającą wydolność wyobraźni masę: tysięcy godzin relacji, mnogości historii, natłoku twarzy na podobnym tle. Jednym z nielicznych świadectw ocalałych, które wyłamują się z tej poetyki, jest znajdująca się w zbiorach Muzeum Pamięci Holokaustu, nagrana w Kijowie relacja Ruwima Izrailewicza Sztajna, który opowiada o swojej brawurowej ucieczce z transportu do Babiego Jaru w miejscu, gdzie wydarzyła się masakra - wytyczając trajektorię sceny ocalenia na płaszczyźnie parkowych alejek i pobliskiej szosy.

Nagranie z rodzinnych zbiorów Wasersztejna można by natomiast zaliczyć do innej sekcji wizualnego archiwum Zagłady: gatunku opisanego przez Janet Walker jako „Holokaustowy dokument powrotu”, reprezentowanego przez filmy (nieraz amatorskie) kręcone przez ocalałych Żydów (lub ich potomków), które dokumentują ich powrót do miejsc w Europie, gdzie spędzili czasy przedwojenne i przetrwali Zagładę ${ }^{20}$. Najciekawszą wariacją

18 Odpowiednio: Jad Waszem: 12 000, Archiwum Fortunoffa przy Uniwersytecie Yale: 4400, Shoah Foundation: 52 000, Muzeum Pamięci Holokaustu w Waszyngtonie (USHMM): 9000 świadectw wideo, za: http://www.yadvashem.org/visual-center/usc.html (18.02.2018) oraz N. Shenker Reframing Holocaust Testimony, Indiana University Press, Bloomington 2015.

19 USHMM, sygn. RG-50.657.0001.

20 J. Walker Moving Testimonies..., s. 270. Walker analizuje dwa przypadki: The Last Days (1998) oraz Hiding and Seeking (2004) - pierwszy nagrany w Spielbiergowskiej stylistyce, łączący materiały archiwalne i nagrania pięciu ocalałych z Zagłady na Węgrzech; drugi - rejestrujący wyprawę syna i córki dwojga ocalałych do miejscowości, w których wychowali się ich rodzice. Takich filmów jest jednak oczywiście więcej: z dominującym motywem powrotu do obozu Zagłady, by wspomnieć choćby o Kitty: Return to Auschwitz (Auschwitz-Birkenau, 1979), Tomorrow Came Much Later. A Journey of Conscience (Majdanek, 1980), Ostatni świadek (Treblinka, 2002); Zvi The Return (Treblinka, 1998); lub rodzinnej miejscowości: Miejsce urodzenia (Radoszyna, 1992), Dzieciństwo w cieniu śmierci (Lwów, Sambor, 2004), Jakby to było wczoraj (2005, Częstochowa), Chutor Konne (Konne, Białystok, 2007), The Last Generation (Żabno, 2011), Shimon's Returns (Brzeżany, 2014), wreszcie pokazujący ocalałych powracających do kryjówki w Jaskini Jeziornej fabularyzowany dokument No Place on Earth (2012). Do pewnego stopnia w genologiczny schemat wpisują się także filmy Mariana Marzyńskiego: autobiograficzny Powrót do Polski (1981), pokazujący pierwszą wizytę reżysera w kraju po wyjeździe w 1968 roku, czy Sztetl (1996) o poszukiwaniu żydowskiej historii Brańska wraz z urodzonym tam Nathanem Kaplanem i lokalnym 
na temat tej formy jest słynne Miejsce urodzenia Pawła Łozińskiego (1992) przedstawiające wizytę Henryka Grynberga w Radoszynie i jego poszukiwania miejsca pochówku zamordowanego przez Polaków ojca. Łoziński tworzy zapis prawdziwego śledztwa na scenie zbrodni: z przesłuchaniem świadków, wizją lokalną, wreszcie odnalezieniem grobu i ciała - dowodu przestępstwa. Świadkami w sprawie są tu mieszkańcy Radoszyny, w tym naoczni obserwatorzy tamtych wydarzeń, postronni Zagłady.

Postronnego ${ }^{21}$ wprowadza na dobre do archiwum wizualnych świadectw dopiero Muzeum Pamięci Holokaustu, które pod koniec lat 9o. rozpoczyna, pod kierunkiem Nathana Beyraka, projekt Perpetrators, Collaborators, and Witnesses [Sprawcy, kolaboranci, świadkowie], którego celem jest nagranie relacji nieżydowskich świadków Zagłady głównie z Europy Środkowej, Wschodniej i Południowej. Do dziś zgromadzono ponad 1900 relacji, a w polskiej odsłonie projektu (1998-2010) nagrano 324 wywiadów: z więźniami obozów koncentracyjnych, z pomagającymi Żydom, a także z naocznymi obserwatorami Zagłady, przede wszystkim mieszkańcami miejscowości położonych blisko obozów śmierci. Relacje wyłącznie postronnych świadków Holokaustu gromadzi natomiast założona w 2004 roku przez księdza Patricka Desbois fundacja Yahad - In Unum. Misją organizacji, definiującej swoją działalność jako z założenia śledczą, jest zlokalizowanie zwykle nieupamiętnionych miejsc „Holokaustu od kul”, czyli egzekucji Żydów i Romów ${ }^{22}$, przeprowadzanych w Europie Wschodniej w ramach akcji Reinhardt na terenie Generalnego Gubernatorstwa i przez Einsatzgruppen na zajętych ziemiach ZSRR. Służą temu dokładna kwerenda archiwalna oraz wyprawy badawcze, podczas których nagrywane są wywiady z naocznymi świadkami wydarzeń (dotychczas 5728 relacji); ekipa fundacji przeprowadza również podstawowe oględziny terenu, ale nie posługuje się zaawansowanymi technikami forensycznymi.

historykiem Zbigniewem Romaniukiem. Niektóre tytuły podaję za: M. Haltof Polish Film and the Holocaust: Politics and Memory, Berghahn Books, New York 2014, s. 218-220.

21 Posługuję się terminem "postronny" dla wyrażenia pozycji bystandera z Hilbergowskiej klasyfikacji (ofiara - sprawca - świadek) uczestników Zagłady. Termin ten zaproponowała Roma Sendyka - por. tekst tejże Od obserwatorów do gapiów. Kategoria bystanders i analiza wizualna w niniejszym numerze "Tekstów Drugich". Zob. też na temat kategorialnych dylematów w odniesieniu do polskich świadków Zagłady E. Janicka Pamięć przyswojona. Koncepcja polskiego doświadczenia zagłady Żydów jako traumy zbiorowej w świetle rewizji kategorii świadka, "Studia Litteraria et Historica” 2014/2015 nr 3/4i J.T. Gross Sprawcy, ofiary i inni, "Zagłada Żydów” 2014 nr 10.

W tym tekście zajmuję się jedynie świadectwami dotyczącymi Zagłady Żydów. 
Po drugie, świadek. Figura świadka w kulturze po Zagładzie to z definicji postać ocalałego: zarówno dzięki setkom świadectw pisanych, jak i źródłom wizualnym, by wymienić choćby transmitowany w telewizji proces Eichmanna, Shoah Lanzmanna, wspomniane archiwa, a także współczesne inicjatywy muzealne używające wywiadów z ocalałymi jako podstawowego elementu ekspozycji. Postać polskiego postronnego, zwłaszcza tego z prowincji, choć do pewnego stopnia reprezentowana w rodzimej literaturze, sztuce, filmie i teatrze, a na scenie międzynarodowej utrwalona w kadrach Shoah, zyskuje w dwóch wspomnianych projektach szeroką reprezentację wizualną. Desbois pisał w autobiograficznej książce relacjonującej genezę projektu, że fenomen jego rozmówców polega na tym, że „nigdy wcześniej nie mówili"23 - szczególnie nikomu spoza własnej społeczności - dlatego naoczni świadkowie wydarzeń muszą często formułować dłuższą opowieść po raz pierwszy, w kategoriach zrozumiałych dla zewnętrznego rozmówcy, wcielając się w rolę lokalnych przewodników. „Nikt się tym nie intereso-

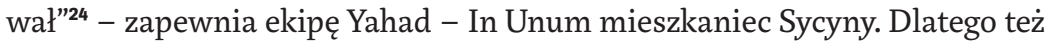
wywiady fundacji mają - przynajmniej w założeniu - otwartą, biograficzno-narracyjną strukturę, ich cel jest jednak zawsze ten sam: relacja na temat losów żydowskiej społeczności.

Świadectwa postronnych - żyjących na obrzeżach Zagłady od dekad („Urodził się i do tej pory mieszkam”, dodaje cytowany powyżej świadek), interpelowanych z zewnątrz, by zreferować nieswoje losy, zrelacjonować nieswoje cierpienie - są więc z zasady niepełne, posiłkowe, drugorzędne: z konieczności dotyczą doświadczeń kogoś innego, a biografia postronnego ma często znaczenie jedynie pretekstowe. Oddalają się tym samym w swej specyfice od katarktycznego charakteru sesji psychoanalitycznej, a zbliżają do przesłuchania bądź zeznania w sprawie: postronny to raczej testis niż superstes, osoba trzecia, a nie ten, którego przeżycie Wydarzenia jest istotą świadectwa ${ }^{25}$. „Dziwię się, że nikt nie chce ze znaw a ć [wyróż. - A.S.], bo tu było nie raz to z 15 osób"26 - oznajmia Tadeusz Przybył z Kalisza (USHMM), opisując Polaków gromadzących się wokół likwidowanego getta.

23 P. Desbois The Holocaust by Bullets: A Priest's Journey to Uncover the Truth Behind the Murder of 1.5 Million Jews, Palgrave Macmillan, New York 2008, s. X.

24 YIU, wywiad nr 10P.

25 G. Agamben Co zostaje z Auschwitz. Archiwum i świadek, przeł. S. Królak, „Sic!”, Warszawa 2008, S. 15 . 
Z drugiej strony składane przez postronnego świadectwo/zeznanie wyrywa go z pluralis gapiów, każe opowiadać w pojedynkę, odsłania jego pozycję. $\mathrm{Z}$ tego powodu - bezpieczeństwa w obrębie własnej wspólnoty - relacje Yahad - In Unum są anonimizowane, tym samym jednak opowieści świadków zdają się do pewnego stopnia pozbawione sygnatury, indywidualnego rysu. Kiedy Lanzmann czy Grynberg raczej przesłuchiwali świadków, nierzadko by unaocznić ich winę, ekipa USHMM czy Desbois i jego współpracownicy nie przekraczają granicy drażliwości, pozwalają postronnemu pozostać w bezpiecznej niszy, być może obojętnego, ale obserwatora, nie dociekają też losów pożydowskiej własności. W przypadku relacji Yahad - In Unum wiąże się to również z faktem, że ich rozmówcami siedemdziesiąt lat po wojnie są przede wszystkim osoby, które tamte wydarzenia przeżyły jako dzieci - niewygodne pytania o udział czy sprawstwo mogą pozostać niejako zawieszone. Równocześnie jednak spektrum postaw Polaków podczas Zagłady pozostaje tym, co archiwum w całości im poświęcone niejako prześlepia.

Po trzecie, krajobraz. Świadectwa z projektu Muzeum Pamięci Holokaustu nagrywane były zwykle w domu świadka, wśród nich jest jednak kilka, które wyłamują się z tej konwencji: na zakończenie rozmowy świadkowie prowadzą swoich rozmówców na scenę zbrodni - w okolice obozu, na miejsce egzekucji lub ulicę, gdzie podczas wojny ustanowiono getto, a wskazywana, identyfikowana i opisywana przez świadka przestrzeń staje się równoprawnym elementem relacji. Wywiady Yahad - In Unum wyprowadzają świadectwo w krajobraz znacznie częściej: odmiennie od dotychczasowej praktyki świadkowie „Holokaustu od kul” nagrywani są zazwyczaj na zewnątrz, obok domu, w ogrodzie lub w sadzie, nierzadko też prowadzą swoich rozmówców na miejsce zdarzeń. Scena zbrodni zostaje więc wywołana w teraźniejszej fizjografii terenu, odtworzona za pomocą wernakularnej toponimii i wymierzona przy użyciu relacyjnych miar definiowanych w odniesieniu zarówno do otaczającej przestrzeni, jak i innych uczestników nagrania, członków filmującej ekipy.„Pod krzakami mieli koniaczki, który przestał strzelać, to przyszedł popić" ${ }^{27}$ - mówi Roman Nosek (USHMM), który został zmuszony do pomocy przy egzekucji tarnowskich Żydów, a kamera filmuje porastające teren paprocie. „Demarkacja i inspekcja” przebiega w przestrzeni pozbawionej zazwyczaj jakichkolwiek widocznych śladów przeszłości, a jej jedynym punktem odniesienia jest pamięć świadka, który odmierza granice miejsca egzekucji za pomocą okolicznych drzew i nierówności terenu i poświadcza wskazaniem 
lokalizację wydarzeń. Z kolei w miasteczkach punktem odniesienia są współczesne zabudowania i ulice: „Tu było całe wszystko przez Żydów. Nasz dom na prawo, Symcha zaraz na lewo” - mówi świadek z Klimontowa (YIU); „Idziemy do getta" - oznajmia rozmówca z Lubaczowa (YIU) ${ }^{\mathbf{2 8}}$, prowadząc za sobą członków ekipy fundacji.

Jeśli pojawienie się posttraumatycznego i idyllicznego zarazem krajobrazu Europy Środkowo-Wschodniej w usytuowanych świadectwach USHMM było przypadkowe, stanowiło raczej efekt uboczny poruszonej kamery ${ }^{29}$, dając dowód wyczuwalnej niecodzienności sytuacji „wyjścia w teren”, w przypadku relacji z archiwum Yahad - In Unum, kręconych zazwyczaj w ciepłej porze roku, krajobraz staje się istotnym elementem przedstawienia: świadkowie często fotografowani są w samotności na tle lasów, łąk i pól ${ }^{30}$, a długich ujęć otaczającej przestrzeni nie sposób nie czytać jako kontynuacji konkretnej konwencji przedstawiania. Tą tradycją wizualną będzie oczywiście „stylizowana nieprzedstawialność"31 Shoah Lanzmanna, a obecna już w Nocy i mgle Resnais'go: szerokie, puste kadry skupione na pogrążonym w spokoju krajobrazie - przestrzeni, gdzie „nie ma już nic więcej do zobaczenia”32 - które przez kontrast podkreślać mają grozę przeszłych wypadków ${ }^{33}$.

Po czwarte, rekonstrukcja. Shoshana Felman w swoim eseju o Shoah Lanzmanna pisze, że świadectwo to „bezwzględnie pojedyncze i niemożliwe do zastąpienia topograficzne us y tu ow a ni e [wyróż. oryg.] w stosunku do wydarzenia", a każdy z Hilbergowskiej triady dostarcza nam innego „performansu aktu widzenia"34. Opowiedzenie historii in situ, powtórzenie sceny zbrodni z konieczności wymaga ponownego umiejscowienia, zajęcia

28 YIU, wywiady nr 573P, 411P.

29 Por. np. świadectwo Stefana Kucharka z Małkini, USHMM, sygn. RG-50.488.00o6.

30 Tak dzieje się np. w wywiadach przeprowadzonych w Sycynie (10P), Łomazach (16BP), Białej Podlaskiej (24P), Lucie (31P), YIU.

K. Ball For and against the Bilderverbot: The Rhetoric of "Unrepresentability" and Remediated "Authenticity" in the German Reception of Steven Spielberg's "Schindler's List", w: Visualizing the Holocaust: Documents, Aesthetics, Memory, ed. by D. Bathrick, B. Prager, M.D. Richardson, Camden House, Rochester 2008, s. 168.

32 G. Didi-Huberman Site inspite of All, w: Claude Lanzmann's "Shoah". Key Essays, ed. by S. Liebman, Oxford University Press, Oxford-New York 2007, s. 114. Por. A. Szczepan Krajobrazy postpamięci, „Teksty Drugie” 2014 nr 1.

34 S. Felman The Return of the Voice, w: S. Felman, D. Laub Testimony: Crises of Witnessing in Literature Psychoanalysis, and History, Routledge, New York 1992, s. 206, 208. 
pozycji wobec opisywanych wydarzeń: obserwatora lub uczestnika. Co więcej, to przestrzenne położenie czasem skutkuje teatralnym włączeniem się w opowiadaną historię: świadkowie mogą odegrać scenę z przeszłości, angażując podążających za nim członków ekipy i wyznaczając im role w wizji lokalnej po latach. I tak w relacji z Klimontowa (YIU) niespodziewanie świadek, skądinąd z przejęciem i żalem wspominający dzieje żydowskich obywateli miasta, opisując egzekucję, podnosi laskę w geście naśladującym strzelanie; z kolei świadek z Siemnic koło Lublina (YIU), opowiadając z widocznym przejęciem o kaźni miejscowych Żydów, klęka na ziemi, chwytając za rękę tłumacza, by odtworzyć ostatni gest idących na śmierć' ${ }^{\prime 3}$. Najczęściej jednak postronny podtrzymuje rolę obserwatora, zmieniając jednak swoje położenie podczas odgrywania zdarzeń: stojąc na miejscu egzekucji, patrzy w stronę kryjówki, z której obserwował wydarzenia ${ }^{36}$; zamiast odtwarzać przeszłość z tego samego punktu, zajmuje miejsce oprawcy ${ }^{37}$. Świadek z Kobylan (YIU) odtwarza wydarzenia z przeszłości w leśnej scenerii, przydzielając członkom ekipy role sprawców i ofiar, a dla siebie wybierając pozycję obserwatora - twierdzi jednak uparcie, że nie był naocznym świadkiem ${ }^{38}$. Scena zbrodni powtarza "performans aktu widzenia" wedle uznania narratora zdarzeń, czasem go jednak zdradzając: topograficzne rozeznanie świadka z Kobylan jasno wskazuje na niego jako, choćby ukrytego, uczestnika wypadków.

Nichols pisze, że „odegrane wydarzenie wprowadza fantazmatyczny element, którego brakuje początkowej reprezentacji samego wydarzenia"39. Ten fantazmatyczny aspekt rekonstrukcji dobrze widać w dystrybucji ról, ale i widzialności na scenie zbrodni: powszechne są zatem historie o ruszającej się ziemi kilka dni po egzekucji, ale mniej częste deklaracje aktu widzenia w trakcie wydarzeń - interwał czasowy stanowi bezpieczny bufor, przyjście „po” i pozycja spóźnionego świadka zdaje się nie obarczać odpowiedzialnością. Stąd też tak częste opowieści o niewytłumaczalnym zniknięciu Żydów, historie o żydowskich domach bez ciągów dalszych,

35

YIU, wywiady nr 573P, 147P.

YIU, wywiad nr 148P.

Wywiad ze świadkiem w Radecznicy, w ramach projektu „Nieupamiętnione...", wraz z R. Sendyką i M. Kobielską, 03.09.2016.

YIU, wywiad nr1P.

B. Nichols Documentary Reenactment..., s. 73. 
wymigiwanie się od naoczności ${ }^{40}$. Scena zbrodni to równocześnie symulacja i stymulacja, by posłużyć się parą pojęć zaproponowanych przez Dorotę Sajewską i Dorotę Sosnowską ${ }^{41}$ : świadek odgrywa przeszłość, dostosowując ją do bardziej akceptowalnej wizji teraźniejszości, równocześnie jednak pozwala wydarzeniom wybrzmieć z niebezpieczną dla jego własnej pozycji autentycznością. Joshua Oppenheimer, reżyser filmu The Act of Killing, którego tytuł w polskim przekładzie - Scena zbrodni - tylko utrwalił ferowaną przeze mnie językową kalkę, tak mówił o bohaterze swojego dokumentu, indonezyjskim zbrodniarzu Anwarze Congo, którego podczas odgrywania sceny morderstwa z przeszłości chwytają gwałtowne torsje: „To jedno i drugie [performans i rzeczywistość - przyp. A.S.]. Gra przed moją kamerą, jest jej świadomy i myśli o niej. Ale równocześnie odgrywa to w taki sposób, że pozwala, by przeszłość uderzyła go w danym momencie z niespotykaną mocą"42.

Po piąte, struktura czasowa. Te szczególne świadectwa in situ, performatywne sceny zbrodni, których podstawowym zadaniem jest deiktyczne wskazanie, zaświadczenie gestem, gdzie doszło do przeszłych wydarzeń, mogą dotyczyć zarówno pojedynczych wypadków: rozstrzelań, drogi na egzekucję, pobić, jak i rozciągniętych w czasie struktur życia społecznego, takich jak życie w getcie, ukrywanie się, transporty. Jeśli w pierwszym przypadku wskazywane przez świadka miejsce będzie punctum zarośniętego roślinnością, niewidocznego już dziś miejsca kaźni lub pochówku, w tym drugim sceną zbrodni są często niezmienione od dekad zabudowania małych miasteczek, w których getto nieoddzielone było od reszty miasta żadną granica, a dzisiejsza bliskość strony aryjskiej i niearyjskiej tylko wyostrza tragizm rozdziału polsko-żydowskich losów w czasach Zagłady. Świadectwa postronnych często łączą więc w sobie opowieści dokumentujące wszystkie trzy fazy

40 O "niewidzeniu" jako postawie rzekomo niezaangażowanych świadków Zagłady i strategii neutralizowania własnej pamięci zob. M. Fulbrook A Small Town Near Auschwitz: Ordinary Nazis and the Holocaust [e-book, format epub], Oxford University Press, Oxford 2012.

41 D. Sajewska, D. Sosnowska Wstęp: symulacje i stymulacje, w: Robotnik. Performanse pamięci, red. A. Adamiecka-Sitek, D. Sajewska, D. Sosnowska, Instytut Teatralny im. Zbigniewa Raszewskiego - Instytut Wydawniczy Książka i Prasa, Warszawa 2017, s. 15.

42 E. Morris The Murders of Gonzago, "Slate" 10.07.2013, http://www.slate.com/articles/arts/history/2013/o7/the_act_of_killing_essay_how_indonesia_s_mass_killings_could_have_slowed.html (18.02.2018). Zniesienie opozycji między "performansem" $i_{\text { }}$ rzeczy wistym" w kontekście filmu Oppenheimera postuluje Janet Walker, tejże Referred Pain: "The Act of Killing" and the Production of a Crime Scene, "Film Quarterly" 2013 Vol. 67, No. 2, s. 16. 
Zagłady: gettoizację, wywózki, ukrywanie i Judenjagd ${ }^{43}$, a na scenie zbrodni wydarzenia nakładają się na siebie we wspólnym mianowniku topografii. Tadeusz Przybył z Kalisza (USHMM) opowiada, przechadzając się po ul.Złotej, o likwidacji getta, której był świadkiem, by za chwilę w przerysowanym pochyleniu głowy naśladować Żydów, którzy musieli kłaniać się Niemcom po rozpoczęciu okupacji w 1939 roku. Spacer jako forma świadectwa stwarza szczególne warunki, by pokazać zarówno tę tak złudną, jak nieznośną bliskość Polaków i Żydów podczas wojny, jak i długie trwanie przemocy, „przyczynowy łańcuch, który doprowadził do Zagłady" ${ }^{44}$, jak pisze Mary Fulbrook: rozłożone w czasie, pozornie bierne uczestnictwo w stopniowym podziale przestrzeni na widzialną i niewidzialną, w konsekwentnym procesie odbierania godności swoim żydowskim sąsiadom. „Ja nic, ojciec nic” - mówi świadek z Lubaczowa (YIU) i zatrzymuje się pod kościołem, opisując, jak w tym miejscu spotkali prowadzonego przez żandarma żydowskiego znajomego, który zawołał ich po imieniu, chcąc się pożegnać ${ }^{45}$.

Po szóste, ramy. Nieoznaczone miejsca Zagłady jako scena zbrodni były ustanawiane i ramowane wielokrotnie i w różnych formach: np. w 1968 roku w ramach akcji ankietyzacyjnej Głównej Komisji Badania Zbrodni Hitlerowskich w Polsce, dzięki której zidentyfikowano setki miejsc egzekucji i grobów masowych na terenie całego kraju. Podobny potencjał miały tworzone przez Związek Harcerstwa Polskiego w latach 6o. alerty - karty „znalezionych miejsc walki lub męczeństwa”, również ludności żydowskiej, zawierające opis rodzaju obiektu, dane historyczne i ich źródła, dokładną lokalizację, a także informację, kto opiekuje się miejscem, opis możliwości jego upamiętnienia i szkic terenowy ${ }^{46}$. Za taki gest ustanowienia sceny zbrodni można także uznać działalność upamiętniającą indywidualnych mieszkańców, by wspomnieć choćby Stanisława Zybałę z Radecznicy na Roztoczu, który nie tylko przez całe życie odwiedzał rozsiane wokół miejscowości miejsca egzekucji Żydów, ale także oznaczał je, nanosił na mapy (jeden z rysowanych przez niego planów wsi z zaznaczeniem lokalizacji zbrodni trafił do Komisji Rabinicznej ds. Cmentarzy z prośbą o upamiętnienie miejsca), pisał przewodniki

43 Periodyzacja proponowana przez badaczy z Centrum Badań nad Zagładą Żydów, zob. B. Engelking Jest taki piękny słoneczny dzień... Losy Żydów szukających ratunku na wsi polskiej 1942-1945, Stowarzyszenie Centrum Badań nad Zagładą Żydów, Warszawa 2011, s. 25.

YIU, wywiad nr 411P.

Np. alert z Szubina z 1965 r., Archiwum IPN, sygn. GK 195/II/17. 
i zarysy historii gminy ${ }^{47}$. Wreszcie ramuje nieoznaczone miejsce ludobójstwa jako scenę zbrodni świadectwo wideo w akcie ustanawiania obrazu, w którym krajobraz oraz gest i głos świadka wyznaczają wspólnie indeks przeszłych zdarzeń. Świadek na scenie zbrodni „z ciągłości i nieskończoności przestrzeni [wykrawa] działkę i [kształtuje - przyp. A.S.] ją w szczególną jedność zgodnie z jakimś zamysłem" ${ }^{\prime 4}$.

W miejscu niewidocznej Zagłady - poprzez „skomplikowane praktyki zaznaczania, obserwacji, obliczeń, interpretacji i przedstawienia",jako wynik fuzji indeksu miejsca i ciała oraz widmowej obecności przeszłości; sprzężenia „autentyczności” gestu, przestrzeni i afektu oraz „teatralności” odegrania, inscenizacji, powtórzenia - powstaje scena zbrodni. Kategoria ta pozwala zinterpretować posttraumatyczny polski krajobraz, sieć miejsc rozproszonej Zagłady, na przecięciu różnych perspektyw badawczych: jako teren forensycznego śledztwa, reprezentację w wizualnych ramach krajobrazu, soczewkę społecznych energii oraz konkurencyjnych praktyk upamiętniania i zapominania, punkt koncentracji afektów i narracji pamięci. Archiwa usytuowanych wideoświadectw postronnych dostarczają materiału dla wszystkich tych słowników, a przede wszystkim umożliwiają rozpoznanie rozpiętości pozycji tych świadków, aktorów pamięciowych performansów, którzy - jak chce Freddie Rokem - pozwalają nam spojrzeć na przeszłość od nowa ${ }^{49}$, choćby na przekór ich własnym intencjom.

47 Zob. np. S. Zybała, M. Zybała Tak Cię widzę Radecznico. Ścieżkami, drogami, miedzami, po krzakach i zaroślach łąk i pól i lasów Radecznicy, Urząd Gminy Radecznica, Radecznica 2000.

48 G. Simmel Most i drzwi, w: tegoż Most i drzwi. Wybór esejów, przeł. M. Łukasiewicz, Oficyna Naukowa, Warszawa 2006, s. 251. Fragment cytowany przez G. Siegla The Similitude of the Wound, s. 97.

49 F. Rokem Wystawianie historii. Teatralne obrazy przeszłości we współczesnym teatrze, przeł. M. Borowski, M. Sugiera, Księgarnia Akademicka, Kraków 2010, s. 28. 


\section{Abstract}

\section{Aleksandra Szczepan}

JAGIELLONIAN UNIVERSITY (CRACOW)

Exhibiting History: The Holocaust Witness on the Crime Scene

Szczepan examines Holocaust bystanders' accounts recorded on video in locations that remain unmarked and unremembered. She proposes to read those videos as visual documents that simultaneously represent and establish such locations as crime scenes. The crime scene - a term that is used in forensic and performative studies - allows us to perceive the unmarked and unremembered locations of the Holocaust as both a reservoir of traces of the past, material evidence, as well as a space for reconstruction of events in performative acts of witnessing. Szczepan uses quotations from over a dozen video testimonies and interprets these documents as acts of recreating and creating crime scenes with respect to six categories: the archive, the witness, the landscape, time structure, reconstruction and framing.

\section{Keywords}

Holocaust, witness, video testimony, crime scene, landscape 